\title{
Christianity in Nigeria before Pentecostalism
}

\author{
Ogunrinade Adewale O. (Ph.D.)
}

E.Mail:Walesoft@Yahoo.Co

Phone: +2348035522497

\section{Ogbole Friday Abu (Ph.D. In View)}

\author{
Department Of Religious Studies, \\ Faculty Of Arts And Social Sciences \\ Gombe State University, Gombe, Nigeria \\ E-Mail: Foabu@Yahoo.Com Phone:+2348036382200
}

Doi:10.5901/ajis.2013.v2n2p121

\begin{abstract}
Many previous works on Christianity in Nigeria had mostly emphasized the successful parts of the mission efforts rather than the whole gamut of attempts, successes, failures and African innovativeness that largely characterized the mission stories. This paper however historically examined in synopsis the mission activities of the missionary groups that made entry into Nigeria and how the religion was eventually slated for indigenization by the Nigerian Christians to aptly express their worldview and perception. Some relevant literatures were used to gather historical facts about the topic. Logical reasoning and historical method were used in treating findings and in reconciling the information and evidence in the literature. The paper surveyed the following: European entry into Africa, Christian entry into Nigeria, (western and southern Nigeria), the missions established and how these missions were breeding diverse African nationalists and charismatic personnel who suggested that Christianity should be expressed in the African way. Christianity in Nigeria had gone through a lot of stages and the roles of these stages are very fundamental in the telling of Christian history in Nigeria. Mission Christianity though brought Christianity to Nigeria could not present a befitting Christianity that match the worldview of the people. Western missionary personnel enjoyed a great deal of hospitality when they came in the 19th Century. Nevertheless, Indigenous Christian practices garnished in Pentecostal expressiveness and liturgies appeared to be the distinguishing traits and hopes of Nigerian Christianity in the long run.
\end{abstract}

\section{European Entry into Africa}

The Europeans came to Africa first at the period of discovery of the western coast of Africa beginning from the middle of the fifteenth century and this brought about the entrenching of the settlement of the European nationals along the coast of Africa. This period was marked with much trading and less evangelism and Christianity was introduced like a rigid institution that had been moderated and tailored according to the western tradition and invested on the African people who had no opportunity to question its presence (L. Sanneh. 1983). The status of the church around this period was just an adjunct of the commercial enterprise and as such had very insignificant appeal to the people of Africa. Though few converts were made around this time including African community leaders and chiefs, Christianity was on shaky ground. The second period of Christian presence in Africa can be dated to the beginning of the eighteenth century when slavery was incorporated to the mission strategy and yet this attempt went the way of the former, as it was not sustainable, though it created the way for the success of the future African missions (David N.A. Kpobi. 2005).

Real success came when mission organizations from Europe and America with the support and participation of many Africans helped in foraging and rooting Christianity on the soil of Africa. Christianity had disappeared in the north of Africa and only a few places like Egypt, Morocco, Tunisia, and Algeria were having some signs of Christian presence. The effort of the Roman Catholic Orders such as the Franciscans and the Dominicans at re-establishing Christianity in this highly Christian part of Africa cannot be disregarded (Kenneth Sawyer \& Youhana Youssef, 2005). This was necessary because Islam penetrated the area and ousted Christianity massively (L. Sanneh 1983). For example, St. Francis of Assisi who founded the Franciscan Order was known to have visited Egypt (a place that accommodated Christianity after jettisoning its Palestinian root), in 1219 during the Fourth Crusade.

Coming to West Africa, the first inroad of Christianity was through the Portuguese catholic missionaries as part of the growing quest for adventure and discovery of new places, since in the past, ignorance, and superstition had marred 
the courage of the few who could have ventured to discover the sub-Saharan Africa. The adventures of the fourteenth and the fifteenth centuries led to the discovery of many parts of the world including the sub-Saharan Africa. Henry, the son of the Portuguese king John I played a vital role by directing a number of expeditions down the western coast of Africa looking for opportunities ranging from trade, scientific, military to evangelism. The four main opportunities that Henry was hoping to assess include; reaching further beyond Cape Bojador, which was the southernmost limits reached by his sailor by then and trying to improve the commercial interests of Portugal by discovering new trade areas where commodities could be bought and sold. Others are assessing the real strength of the Muslim rulers in Africa whom he thought were threat to the Portuguese interests and, expecting to discover the isolated Christian kingdoms believed to exist in Africa (C.P. Groves, 1948-1958).

After many years of expeditions, Henry and his men went beyond Cape Bojador and discovered a large portion of inhabited coastal land. They established trade links with the inhabitants and moved on and crossed River Senegal around 1445. After his death in 1460, Portuguese traders had settled on the island of Cape Verde while some moved on to cross the Gambia River and they got to the coast of Sierra- Leone and Cabo Mensurado, which is the present day location of Monrovia in 1465. They also touched Elmina in present day Ghana and Benin, which is between the present day Nigeria, and Togo (David N.A. Kpobi 2005).

\section{Christian Entry into Nigeria}

Christian origin in Nigeria could also be dated to the Fifteenth Century and as will be envisaged, the attempt by the Portuguese missionaries at Christianizing the people of Benin and Warri failed due to their interest in trade and commerce than mission. In the sixteenth century, the trade gear changed from sylvan products such as wood and associated products to slavery, which went on for more than 300 years. During this period, the Efik people of Old Calabar embraced the culture of the Europeans so much so that they were bearing Anglicanized names and learning the English social manners (E.A. Ayandele, 1966). Though all these were going on, the custom and tradition of the Igbo people that the Efik were then associated or grouped with were unchanged. The people maintained their territories against Christianity though the fascinating cultures and the lucrative trade opportunities of the foreigners were welcomed. The place became so much impregnable that the Europeans concluded that the people were uncivilized. They felt that cuddling Christianity was the only channel to civilization.

In Benin and Warri, J.F. Ade Ajayi expresses that the religion at the beginning of the 14th century was ineffective. He describes the nonchalant attitude of the Oba of Benin who asked that Portuguese missionaries be sent to Benin and when they arrived, he was busy fighting a war in 1515. He dismissed them and suggested that they could return when he had much time that he could spare on leisure (J.F. Ade Ajayi, 1965). When they returned in 1538, the king was no more interested in the religion. Due to this, traditional religion went on and even spread in Benin, and subsequently, Benin's relationship with the white men dwindled greatly. Another effort towards Christianizing Benin came in the middle of the seventeenth century by the Spanish and Italian Capuchins. They speculated that winning the heart of the Oba whom his subjects so much adored might mean winning the hearts of all the subjects, as they would definitely obey him in whatever circumstances. They were however disappointed to be denied access to the king as they saw him only twice-in ten months and they were caged in the rooms provided for them. When they became too much adventurous in 1651 by trying to interrupt a traditional festival involving the use of human being as sacrificial material, they were deported.

The Warri axis of the Niger-Delta did not also prove promising though in 1570, the Olu of Warri was excited about the Christian faith by allowing one of his sons named Domingos sent to Portugal to be educated. The only benefit from this association was that the Warri rulers from 1570-1733 became professing Christians. So Christianity was curtailed to the palace. People were afraid to take their children out for baptism, as they believed that a baptized child would die prematurely. The Christian ritual about marriage was not having any influence on the people and circumcision rites in the traditional way remained. To crown it all, there were no regular supply of clergy to administer the sacraments that held very significantly in the Catholic Church (J.F. Ade Ajayi, 1965). What we could say about this formation in Warri is that at least Christian shadow could be seen in the region and the word "Christianity" was already known and mumbled at least among the rulers.

It will be interesting to mention that the lucrative trade that was brought along with Christianity right from the sixteenth century, that is Slave Trade, which E.A. Ayandele refers to as the "living tool", was abolished in 1807 when Britain passed a bill known as "The Slave Trade Abolition Act" to this effect. Other nations as America and Denmark followed suit. After this, the antislavery movement as Evangelical churchmen, Methodists and Quakers made many 
Campaigns and the British government was overwhelmed with appeals. This led to the passing of the Emancipation Act, which guaranteed that all slaves in British domains were liberated (Jehu Hanciles, 2005). We need to take note that the Mansfield Ruling of 1772 that ruled that any slave who set foot on English soil became a free man took about thirty-five years before it was implemented as, within this period of the ruling and the abolition act, slavery still continued. The vacillation in abiding by this ruling was due to some powerful and influential people in government who wanted this business to continue.

Britain showed her sincerity and commitment in the deal by sending her ships to patrol the seas in the Gulf of Guinea and many arrests were made. With this abolition, effort was made to transport the freed slaves to Africa and resettle them. This is because the slaves were considered not valuable again and must be got rid of the streets of Britain so as not to constitute a social menace to the white society. Sierra Leone was chosen as the best settlement for the freed slaves. The first batch of freed slaves to leave the British soil left on April 8, 1787 for Sierra Leone. The ship was made up of 411 passengers that comprised of ex-soldiers, a handful of European officials, "craftsmen" and their families, and seventy London prostitutes (Jehu Hanciles, 2005). Within three months one-third off the slaves died because of disease and by 1788 , only 130 of them remained. One King Jimmy attacked Granville Town where the remaining of them settled and the whole settlement was completely destroyed. Though this escapade ended in disaster, it nevertheless initiated the beginning of the mass movement of these freed slaves from Britain. This made Britain to be more careful at sending more slaves down to Africa.

A committee was set up to oversee the settlement of the freed slaves and in 1792, another batch of freed slaves totaling 1190 was sent out. This time around, the slaves were those from Nova Scotia who fought for Britain during the revolutionary war. They were promised their freedom and economic opportunities but were abandoned after the war. One Thomas Peter who was also a freed slave arrived in London in 1791 to appeal to Britain to emigrate them from Nova Scotia. This mission was however successful as the already baptized freed slaves landed in Sierra Leone complete with their preachers. The new arrival of slaves named the settlement Freetown. This group of freed slaves was already zealous and spiritually ready to continue in their faith. This was manifested in the establishment of the first black church in modern Africa. It is worthy of noting that Sierra Leone was the first point of entry of the missionaries in West Africa. The Church Missionary Society rolled out its mission plan for Sierra Leone by sending missionaries there to meet the needs of the African Christians.

Many more freed slaves entered Freetown and the religious atmosphere there began to improve. For instance the Nova Scotia group was joined by another group of African slaves called the Maroons consisting of about five hundred and fifty emigrants from Jamaica. Meanwhile, efforts were being made by concerned stakeholders to get the freed slaves comfortable in Sierra Leone. The Sierra Leone Company and other evangelical promoters' keenness towards establishing a Christian commercial centre where good business that will discourage the slave trade business and usher in a new chapter in the African story could be established. This effort yielded many rewards as it fairly helped in getting at least some of them settled. A large proportion of the freed slaves were made up of the Yoruba who even became the largest most organized group. They were popularly called the Aku people (C. Fyfe, 1962).

Just as Sierra Leone is important in the history of West African Christianity, so also the Yoruba freed slaves and the Yoruba language. The ethnic group was the largest and the most cohesive in Sierra Leone then. The language was also well spoken and this occasioned its study by the Church Missionary Society missionaries in Sierra Leone (Modupe Oduyoye, 1969). Bishop Samuel Ajayi Crowther who was the first African Anglican black Bishop also started the translation of the English Bible to Yoruba on his way to Sierra Leone after his ordination in England. Furthermore, the first Christian service to be conducted in Yoruba language took place in Sierra Leone on January 3, 1844 (J.F. Ade Ajayi, 2001). Modupe Oduyoye quotes the speech of Bishop Crowther about the service:

\begin{abstract}
A large number of Africans crowded hither to hear the words of prayer and praise for the first time in their own tongue in an English church. "Although it was my native language with which I am well acquainted, yet on this occasion it appeared as if I were a babe, just learning to utter my mother-tongue. The work in which I was engaged, the place where I stood, and the congregation before me, were altogether so new and strange, that the whole proceeding seemed to myself like a dream. ..At the conclusion of the blessing, the whole church rang with "ke oh sheh"- so be it, so let it be!"
\end{abstract}

As a result of the increase in population of the freed slaves in Freetown, population for agricultural land increased. An initiative of a farm settlement on the bank of the Niger was proposed and the government supported this by sending out three ships with scientists and other professionals while the C.M.S. supplied missionaries and interpreters. This was 
the time when Bishop Samuel Ajayi Crowther was invited to join the company and considered taking up residence at the proposed farm settlement. He acceded to this proposal but he declined to stay on at Lokoja because of his family. The significance of this expedition was that it drew attention to the importance of an African ministry and the likelihood of entry into Yorubaland before the establishment of the farm settlement on the Niger (J.F. Ade Ajayi, 2001).

\section{Missionary Entry into Western Nigeria}

The non-porous nature of the Niger-Delta in the 16th Century to Christianity as has been previously observed went for a long period of time until 1842 when the missionary buildup which used the opposite ends of the Nigerian coast namely Badagry to the south- west and Calabar to the south-south in 1842 and 1846 correspondingly. This time around, much success was recorded as mission changed the political and social development of Nigeria that Islam which had been firmly rooted especially in the Northern Nigeria around 1804-1831 was threatened (E.A. Ayandele, 1966). The missionary involvement around this time was fully a mission-oriented escapade as the missionary movements were aware of the past failures whereby Christian influence was made to depend on success in commerce, and were ready to avoid making the same mistake. Mission was faced with the tasks of re-establishing Christianity in Africa and making it formidable, enough to oust the endemic influences that Islam and traditional religion had entrenched. The new missionary movement that surfaced around this time came because of the evangelical revival of the late Eighteenth Century (Jehu Hanciles, 2005). This revival brought about an awakening in the Methodist and the Anglican churches. Europe and America were most touched as Protestants there became more zealous. Many mission-oriented societies were formed that included the Baptist Missionary Society by in 1792 and the Society of Mission to Africa and the East, which later translated to the Church Missionary Society in 1799.

The Wesleyan Missionary Society made history in Nigeria when one James Ferguson who was a Wesleyan convert requested for a missionary from the Wesleyan Missionary Society and Rev. Thomas Birch Freeman was sent. Freeman arrived in Nigeria on 24 September 1842 as the first Methodist missionary to set foot in Nigeria. At this time, some freed slaves (about three hundred) had already settled in Badagry and trade in palm oil had commenced (Modupe Oduyoye, 1969). Mr. and Mrs. De Graft who helped him to look after Badagry while he went to Abeokuta accompanied Freeman. His mission in Abeokuta was to attend to the need of the freed slaveswho requested for missionary. Sodeke, the king of Abeokuta received Freeman warmly, not because of his total love for the Christian mission, but for the fact that Christianity would help him gain some political advantage over his enemies like the ljebu and the Ibadan states. He later proved this when he solicited for the support of the British government against the people of Ado which was between Abeokuta and Badagry. He not only invited Freeman but also others. More missionaries and traders came in thereby improving the Christian firmness and trade potentials of the Egba people. No wonder that later, Henry Townsend also came in (E.A. Ayandele, 1966).

Badagry was the point of entry for the freed slaves and they were warmly received there. Abeokuta where the slaves were planning to settle was also made comfortable for them due to the politics of power that existed then. The political intrigue between Akintoye and Kosoko in Lagos made Lagos a divided zone for the freed slaves. Kosoko his nephew deposed Akintoye who considered himself the rightful heir to the throne of Oba of Lagos in 1845. Akintoye was interested in regaining the throne and he supported the missionary and its establishment in Lagos as he thought that the missionary could be of help in reclaiming his kingship. Kosoko on the other hand did not want to loose the throne and he considered the missionary as a threat to watch. Therefore, he supported the anti-missionary party in Lagos. As will be expected, the freed slaves were badly treated in Lagos due to the position of Kosoko. As a result of this, the slaves preferred to come in through Badagry and settle either there or Abeokuta ((E.A. Ayandele, 1966).

The second missionary society to enter the Yoruba Mission was the Church Missionary Society about the end of 1842, precisely 17 December. A small sailing vessel named "The Wilberforce", entirely manned by Negro sailors and owned by a Negro arrived at the port of Badagry that year and Henry Townsend who had traveled in that ship free of charge disembarked. Andrew Wilhelm, who was a class teacher from Bastings, accompanied him and his church members paid his passage. Townsend, though a C.M.S, missionary did not disregard Freeman's guidance as he met him and got help from him. Oduyoye says that they worshipped together in the Methodist Church on Charismas day before Townsend left for Abeokuta on 29 December 1842 (Modupe Oduyoye, 1969). Just as Townsend returned to Badagry to move his team back to Abeokuta and start his missionary work, Sodeke, the king of Abeokuta, who had been of great help to the missionaries against many hostilities including the one from Kosoko in Lagos, died. Therefore, the C.M.S. 
team had to wait in Badagry for eighteen months. It was the period of waiting that culminated in the establishment of the C.M.S. Church in Badagry.

The first service was held on 9 March 1845. They made some efforts to convert the rulers of Badagry to Christianity but their efforts were met with resistance because slave trade was still booming there and those who were benefiting from this trade were reluctant to allow Christianity and the missionaries who would kick against their trade. The missionaries proceeded to Abeokuta in July 1846 where it fruited exceedingly. The relationship between the missionaries and the Egba rulers could best be described as a symbiotic one. The missionary activity helped in checking the intrusion of Dahomey because they might have captured Abeokuta if not for the military intervention of the British Government (E.A. Ayandele, 1966). Though this relationship did not later paid well for the Egba people as this made them to remain perpetually the subject of the British government and the missionaries yet, they enjoyed the British support in many ways including, the ousting of Kosoko the king of Lagos in 1851. The implication of this relationship on Abeokuta was that Abeokuta was becoming prosperous in trade, development and politics of the Yoruba region. Abeokuta had a large number of liberated slaves and missionaries who were factors in the development of the place. The British on their own part were acquiring Nigeria politically as they were becoming relevant in the political and religious spheres of the city. The great and powerful influence of Dahomey over the states in the southwest of the then Nigeria especially Abeokuta, was immerse. Dahomey would have conquered Abeokuta if not for the missionary propaganda demonstrated by the missionaries from 1846 to 1860 (E.A. Ayandele, 1966). The military defense put up by the missionaries and the direct aid by the British Government helped to maintain the existence of the city until 1891 when the French Army attacked Dahomey.

Oduyoye in his work described further why Egba was so important to the missionary and Abeokuta a home to their missionary activities (Modupe Oduyoye, 1969). Abeokuta was a home to all, and in addition a city of refuge for those dispersed by war. Refugees from conquered Egba towns came there to resettle. As from 1821 which marked the beginning of the Owu war, and 1830 when settlements of the dispersed refugees started to surface in Abeokuta, inhabitants from not less than one hundred and forty five towns and villages had resettled in Abeokuta. Furthermore, recaptives from Sierra Leone, along the coast had from 1839 learnt about the new town and had settled there by 1842 (Modupe Oduyoye, 1969).

Despite this seemingly cordial relationship, some of the Abeokuta people saw the overbearing attitude of the missionaries. The people developed a degree of distrust against them. They said that the white men only came to taps their lands resources, force them to obey their foreign rules and later dominate them as they (the missionaries) did for Lagos (E.A. Ayandele, 1966). The presence of the British in Lagos led to the enthronement of Akintoye (after Kosoko had been deposed), who signed a treaty, which made Lagos a protectorate of the British Government. The British had been poking into the affairs of the Yoruba people, the intertribal wars, and taking sides from Lagos to buttress this claim, Oduyoye categorizes the missionaries as being part of a threefold programme called the three C's, that is, Christianity, commerce, and civilization. He describes that the missionaries were actively involved in the three progammes and they explored every means to bring this to reality. The missionaries were however useful in adding to and improving the skill levels of the indigenous Abeokuta people by teaching them skills such as carpentry and brick making. They also increased the proficiency of the people in agriculture by introducing them to the commercial culture of rice planting and cotton cultivation. Also, a printing press where much of the publishing then, especially in Yoruba language were done was established (Modupe Oduyoye, 1969).

The Church Missionary Society's missionary adventure into Yorubaland recorded enormous successes in all ways. These included setting up an Anglican Mission in Badagry, opening up of the Niger for lawful trade and the significant fruitful outcome of the Thomas Fowell Buxton led expedition, which led in no small means to the expansion of Christianity in Nigeria.

\section{Missionary Entry into Southern Nigeria}

The third missionary society in Nigeria was the Scotland Mission, known as the Presbyterian Church. The Scotland Missionary Society started its work in Nigeria in 1846 through the initiative and the willingness of the Jamaican Presbytery. The Scotland Missionary Society, which was formerly known as the Edinburgh Society since 1796 set up the Scottish Mission in Jamaica in 1824. Another missionary body known as the United Session of Scotland also started its ministry in Jamaica and through the merger of the two societies, the joint Presbyterian Church in Jamaica was formed (J. Kofi Agbeti, 1986). As from 1839, the Presbytery started to think about sending a mission to Africa. This was because 
the Negroes of the Presbytery began to have great concern for the indigenous peoples in Africa and G. Blyth expressed this concern in Kofi Agbeti's work as

\begin{abstract}
"Our emancipated people finding their condition so much improved by freedom, and appreciating their Christian privileges began to commiserate their brethren in Africa... All our congregations held meetings for consultation and prayer about their subject, and also began to form a separate fund for the benefit of Africa, which in the cause of a little more than a year amounted to six hundred pounds. In these efforts they were stimulated by the Baptist congregations, especially that of Mr. Knibb" (J. Kofi Agbeti, 1986).
\end{abstract}

After adequate information were gathered about the continent of Africa, between 1839 and 1840, the presbytery took a decision in 1841 to send a mission to Africa, and the missionaries agreed to conscript eight missionaries. However, the overall Scottish Missionary society was skeptical about this Jamaican resolution, (reflecting on the outcome of the Niger Expedition in the 1840's which was not fruitful as expected), the Jamaican Presbytery war resolute.

The first missionary of the Presbytery was sent to Calabar under the leadership of Rev. Hope Masterdom Waddel, his wife and another Scottish couple who all arrived in Calabar in 1846 (J. Kofi Agbeti, 1986, S.A. Fatokun, 2005, Deji Ayegboyin and F.K.U. Asonzeh, 2002.) Prior to the arrival in 1846, two men George Blyth and Peter Anderson, who were both Scottish Missionaries in Jamaica were recuperating in England after falling ill in Jamaica and they met sea captains who had known the Old Calabar to be a very fertile area for missionary work. These captains advised them to look unto that direction for a result oriented missionary work. The two missionaries sent a letter to the chiefs of Old Calabar showing their willingness to come over for missionary purposes and the reply was enthusiastic. The Calabar chiefs conceived that the presence of the white missionaries would increase their trade chances with other parts of the world and further give them and their children great avenues to be taught how to read and write fasters. The chiefs of Duke and Creek towns had encouraged the missionaries whom they accommodated to instruct their people and introduce the town people to legitimate trade, apart from trade in slaves.

Blyth and the other Presbyterian missionary Peter Anderson, who led the 1846 mission tour acknowledged the chief's invitation and made their findings known to the Governor of Fernado Poat, Captain Beecroft interviewed the chiefs of Old Calabar and they re affirmed their earlier acceptance of the white missionaries. Fernado Poat communicated Jamaica about this and in 1844, Jamaica resolved to send a missionary society to carry out the mission to Calabar. H.M. Waddel was asked to return to Scotland and lead a mission to West Africa. Eight people in all sailed from Liverpool on 6 January 1846 and they got to Calabar in 10 April 1846 (J. Kofi Agbeti, 1986).

\title{
5. The Baptist Mission in Nigeria
}

The work of the Baptist mission in Nigeria could be traced to the mission voyage of Thomas T. Bowen, Harvey Goodale and Robert F. Hill who were commissioned and sent as missionaries to central Africa. (Northern Nigeria), on 22 February 1849. They had stopover in Liberia to acclimatize before moving on to their destination. Unfortunately, Harvey Goodale died in Sama country. Bowen left Monrovia in Liberia, sailed for Badagry, and planned to move to Igboho, which was about 200 miles north of Lagos (Peter Falk, 1997). Due to the wars in the Yoruba areas, the roads that could lead him to Igboho closed down and he could only get to Abeokuta. For a period of eighteen months, Bowen stayed in Abeokuta and was the guest of the king and of the Church Missionary Society and other missionaries there (Modupe Oduyoye, 1969).

Though Bowen could not start his work at Igboho as he had planned, his stay in Abeokuta was not futile as he was engaged in the study of Yoruba language and vocabulary. He ended up publishing a book titled, Grammar and Vocabulary of the Yoruba Language (Kofi Agbeti 2005) in 1862. He visited the king of Ketu who warmly received him but due to the intolerance of his chiefs, the king had to advise Bowen to leave. However, he was invited later, he did not honor this invitation as he had received an invitation from ljaye in 1852 to come and visit them (Modupe Oduyoye, 1969). ljaye was a city with a population of about forty thousand people (Peter Falk, 1997). Kurunmi, the chief of ljaye who invited him asked him to select any site of his choice for his mission and after choosing a site, he ran into series of problems, which ranged from lack of money to build a house, to his poor state of health (Modupe Oduyoye, 1969). He had to go back to the United States of Americas (Peter Falk, 1997).

Bowen returned to Nigeria as a newly wedded man. He also came with two other couples to start the missionary adventure. They included J.H. Lacy and his wife and J.S. Dennard and his wife. However, due to the scourge of malaria, the Lacy's were sent back home while the Dennards died The Bowens got to ljaye and erected a chapel there in 1854 
and having consolidated their mission at ljaye by making one Mr. Clarice to take up the new ministry, they moved to Ogbomoso. Bowen's work in Ogbomoso was however successful (Modupe Oduyoye, 1969).

Ogbomoso around this time was under a siege ironically created by the missionaries. The American Baptist Missionary Society that Bowen was representing was already posing "great threat to the traditional establishment of the town as many converts had been made. One of them was Barika who was the first convert and who had started to defy the Bale, the chief of the town. Later the hostility against the Christians resulted in violence E.A. Ayandele, 1966).

Apart from the ljaye and Ogbomoso stations, other stations were established and they included Oyo, Shaki, Igboho, and llorin (S.A. Fatokun, 2005). In all the Baptist Mission's story among the Yoruba and in Nigeria was a success.

\section{The Catholic Mission in Nigeria}

The catholic missionary establishment started to enter Nigeria as from 1860, when the Society of African Mission (SMA) vicariate Apostolic of Dahomey made the move. Father Francesco Borghero who was an Italian priest in the Diocese of Genoa led the first team of missionaries to Dahomey in 1861.

On February 17, 1862, Father Borghero visited Lagos and was overwhelmed by the great reception accorded him. Before this visit he had chosen a place called Ouidah in Dahomey where a considerable number of repatriated slaves were settled, and established Roman Catholic community consisting of "quasi - African Catholics" (Kofi Agbeti 2005).

Lagos around this time was free from the violence of the wars that it has sustained, especially the 1851 bombardment by the British. The British as we have mentioned earlier took side by supporting Akintoye against Kosoko. Kosoko was deposed as king and Akintoye signed a treaty with the British to discontinue slave trade and to allow safe and legitimate businesses to take place. This peaceful environment attracted many people who had fled Lagos to come back. There were Brazilian Catholics who had been expelled from Lagos in 1851 and also missionaries and peoples from Sierra Leone and Cuba who all took advantage of the peace in Lagos to return. These were the people who welcomed the priest in 1862.

However, before the official visit of Borghero to Nigeria, priests occasionally visited Lagos and other Catholic communities along the coast from Sao Tome Island (Modupe Oduyoye, 1969).

After his departure, the Brazilian community continued to expect that Father Borghero would return to set up a permanent mission in Lagos. In 1868, he returned and set up a station in Lagos and put Father Bouche as the superior of the station. However, Father Bouche did not stay long in this station. Father Courdioux as the superior of Dahomey replaced Father Borghero and he transferred Father Bouche to Agoue and made Father Cloud the new superior of Lagos (Kofi Agbeti 2005, Modupe Oduyoye, 1969).

Father Cloud's contribution to the development of agricultural settlement yielded good results. His vision was really in line with the general Roman Catholic educational policy of the time, to train children to make use of their intellects and hands. It was believed that through this, an independent mind that would be resourceful to the family and society could be built.

According to Kofi Agbeti, Father Clouds initiative was boosted by a Roman Catholic lay man called Sir James Marshall, an English trader and a supreme judge for Lagos and Cape Coast who advised Cloud to ask the Governor of Lagos for a nine-mile strip of land at Topo which was along the coast near Badagry (Kofi Agbeti 2005).

Modupe Oduyoye in his own account says Father Borghero who received the grant of the land (Modupe Oduyoye, 1969). However, we wish to infer that the report of J. Kofi Agbeti seems accurate as at the time the land was granted, Father Borghero had seized to be superior of Dahomey and could not have been given the land. The land was granted on 26 July 1876 and Topo was given its first superior, in Father Poirer under whom Topo developed greatly. Under the arrangement, Topo was a free zone for local Nigerian families, who were offered residence there. The condition for staying there was to farm and the beneficiaries would pay back their rent in kind, and assist in clearing and cultivating farmland. This system was to do focus the youths from depending on clerical profession from the government alone. Youths were taught to use their mind to learn agricultural and other vocational skills and be productive. This achievement soon suffered set back because of the drift of youths and children on the farmland from the settlement to towns such as Lagos and Porto-Novo (Modupe Oduyoye, 1969).

Despite this, the achievement of the settlement cannot be de-emphasized. This was because hundreds of acres of land had been cleared and many thousands coconut trees had been cultivated. In addition, herds of cattle and plantations of cassava were in place and the crops were thriving very well. This settlement further helped in establishing orphans and slaves who were previously unsettled. In addition, a convent was established in 1892 for girls (Kofi Agbeti 2005). 
The confirmation of the Catholic mission in Lagos came in 1877 and in 1878, when the construction of the Holy Cross Cathedral was started more attention and credence were accorded to the mission in Lagos. This construction of the Church was completed in 1881. In all, the Catholic mission recorded enormous achievement because the fathers were supported by the local people. They were further assisted by the Catholic Nuns, who were workers of the Franciscan Sisters of the Propagation of the Faith in Lyons.

The Holy Ghost Fathers is another catholic order that came to Nigeria through the Eastern part of the Nigeria. The order came to Onitsha in Nigeria in 1885 to establish the Roman Catholic Church (J.F. Ade Ajayi, 234). By 1889, Onitsha had been accorded the stations of a province known as the Ecclesiastical Province of Onitsha that was to oversee the whole of the Eastern part of Nigeria. The Holy Ghost Fathers later made their in road to the northern part of Nigeria by establishing a station at Lokoja in 1884 and founding the Ecclesiastical Province of Kaduna in 1911 (S.A. Fatokun, 2005). The presence of the Roman Catholic Church in Nigeria cannot be told without mentioning the two Catholic Orders that endeavored to wade through the tide to establish the Catholic Mission in Nigeria.

\section{Other Missions in Nigeria}

Qua Iboe Church: Samuel A. Bill founded the Qua Iboe Church in the Eastern part of Nigeria as an interdenominational mission through the inspiration of one $\mathrm{H}$. Grattan Guinness. The mission started in the Qua Iboe River valley in the Eastern part of Nigeria in 1887. By 1890, a church had been formed and around 1891, friends from North Ireland supported this group even when opposition was coming from the primitive Methodists (Peter Falk, 1997, Ogbu U. Kalu 1978, J.F. Ade Ajayi 2001, Deji Ayegboyin and F.K.U. Asonzeh 2002). In 1898, about three hundred members were already communicants.

Sudan Interior Mission: The next mission to look into is the Sudan Interior Mission, which sent three missionaries namely Walter Gowans, Thomas Kent, and Rowland Bingham to the Northern region of Nigeria. Though the effort of the (SIM) to establish a church in this region failed, another attempt became fruitful in 1901 when some churches were established. The churches founded by this mission were later christened Evangelical Churches of West Africa (ECWA) in 1893. In order to assist the Sudan Interior Mission in its evangelistic works, the Sudan United Mission was formed. The S.U.M. was able to establish six churches (Deji Ayegboyin and F.K.U. Asonzeh 2002).

So far, all the churches and missions that we have discussed are referred to as historical, "mainstream," or "established" churches since they have had a line of history that antedates their presence in Nigeria. This study takes us next to look into the churches that came out of some of these historic churches that we have mentioned in Nigeria.

Advent of the Ethiopian Churches: Forerunners of Indigenous Churches in Nigeria: The Ethiopian Churches were established with a view to promoting a church financed and governed by Africans (Deji Ayegboyin and F.K.U. Asonzeh 2002). Ethiopian Churches reject European leadership, though they do not jettison some of their doctrinal and organizational apparatuses of their parent churches. These churches despised the over bearing nature and attitude of rulers of the European mission churches.

Fatokun in his work says that the main reason for the formation of the Ethiopian Churches was to correct the colonial Christianity and imperialism, which the foreign missionaries invested on Africa (S.A. Fatokun 2005). The churches that revolved during this period are referred to as the African Independent Churches C.S. Ola traces the beginning of this brand of church to a protest against the forms of church government in the Church Missionary Society and the willingness to enter fully into the Christian communion. It was an age of knowing or the renaissance period of Christianity in Nigeria (C.S. Ola 1969). He describes further that due to the ill treatment of the Nigerian Clergy in the C.M.S., and the way and manner that the Colonial government and missionaries regarded the indigenous cultures of the Nigerian Society, Nigerian clergy and "laymen" rose to the challenge and severed their relationships with the mission churches (C.S. Ola 1969).

The churches that emanated from this action included the Native Baptist Church which seceded from the southern (American) Baptist Convention in March 1888, the United African Church (U.N.A.) which was co-founded in 1891 by those who broke away from mission churches as Anglican Methodist, Baptist and others. The third was the African Church Bethel, which came out of the Anglican Communion in October 1901 and the United African Methodist Church (Eleja) which broke away from the Methodist Church in 1917(S.A. Fatokun 2005, Deji Ayegboyin \& S. Ademola Ishola, 1997, S.A. Adewale, 1985). 
The African independent churches 'protested the shabby and undignified treatment given to Bishop Ajayi Crowther and the Nigeria Delta pastorate, and the hostile treatment meted on Bishop James Johnson by the English clergy. Other reasons included the enforcement of monogamy on the members of the church and the order to divorce second or third wives as a pre-condition to receiving the Holy Communion. In addition, the yearning for "democracy" and "self government" and their fondness for Nigerian clergy were some of the reasons that the African Churches evolved (C.S. Ola 1969). S.A. Adewale puts the story in retrospect by reviewing the 1888 episode where Ladejo stone was dismissed by a young American Baptist Pastor because he asked for an increment in his remuneration. The pastor took the decision without first referring the case to the Baptist Church as the constitution recommended. When he would not rescind his decision, some members started to withdraw. These members formed the Native Baptist Church. Adewale further claims that the other African churches seceded from their mother churches due to the lack of concern of the white missionaries (S.A. Adewale, 1985). For example, the African Church (incorporated) which was founded in 1901 saw a large pullout of members of St. Paul's Breadfruit (Anglican Communion). About six hundred members withdrew to form this new church (S.A. Adewale, 1985). Though this brand of church was formed to redress the bad situation in which the European missionaries regarded the indigenous culture of the people, yet the vacuum could not be filled as expected in that the spiritual yearnings of the Africans and the emotional and expressive Christianity, which could fit into the cultural worldview, was lacking. The African Christians wanted a Christianity that would picture their society, culture, and values. They desired a Christianity that recognizes African indigenous cultural worldview and uses this as a medium of communicating the Christian message and expression to them. They would not have seceded from the mission churches in anyway if they had not been culturally slighted as the missionaries did. Even though the Ethiopian churches came up to rid the Europeans of their dominance, solution to the problem of African Christianity still lingered.

The Christianity needed by the African Christians was the type that could address the daunting problems by the wicked forces that fly in the air at night. They expected a force that could equally assuage the forces of the evil powers that were tormenting their daily existence. Since Mission Christianity had failed in providing a substitute, a potent alternative to the indigenous means of solving the daily existential challenges, which the local people had been solving through the consultation of oracles and divinities was required. There was the need to accommodate a spirituality that could solve these daunting problems. The search for this spirituality continued.

\section{References}

Ade Ajayi, J.F. 1965, Christian Mission in Nigeria, 1841-1891: The Making of a New Elite, London: Longman Group Ltd.

Ade Ajayi, J.F. 2001. A Patriot to the Core: Bishop Ajayi Crowther, Ibadan: Spectrum Books Ltd.

Adewale, S.A. 1985. "African Church Movement and their impact on Social and Religious Life in Nigeria". The Gods in Retreat: Continuity and Change in African Religion, Enugu: Faith Dimension Publishing Co. Ltd.

Ayandele, E.A. 1966. The Missionary Impact on Modern Nigeria, 1842-1914, A Political and Social Analysis, London: Longman Group Ltd.

Ayegboyin Deji \& Ishola, S. A. 1997. African Indigenous Churches: An Historical Perspective, Lagos: Greater Heights Publications. Ayegboyin Deji \& F.K.U. Asonzeh, 2002. "Taxonomy of Churches in Nigeria; A Historical Perspective", Orita, Vol.34, No.1-2.

David N.A. Kpobi, 2005. "African Chaplains in Seventeenth Century West Africa", in African Christianity: An African Story. Ogbu U. Kalu (ed.) Pretoria: Dept of Church History, University of Pretoria.

Fatokun S.A., "Pentecostalism in South-Western Nigeria with Emphasis on the Apostolic Church, 1931-2001", Ph.D Thesis submitted to the Department of Religious Studies, University of Ibadan, Nigeria.

Fyfe, C. 1962. A Short History of Sierra Leone, London: Oxford University Press.

Groves, C.P. 1948-1958. The Planting of Christianity in Africa, London: Lutherworth Press

Hanciles, J. 2005. " Back to Africa: White abolitionists and Black Missionaries", in African Christianity: An African Story. Ogbu U. Kalu (ed.) Pretoria: Dept of Church History, University of Pretoria.

Kenneth Sawyer \& Youhana Youssef, 2005. "Early Christianity in North Africa". African Christianity: An African Story. Ogbu U. Ka1u (ed.), Pretoria: Dept of Church History, University of Pretoria.

Kofi Agbeti, J. 1986. West African Church History: Christian Mission and Church Foundations 1842-1919; Leiden: E.J. Brill.

Lamin Sanneh, 1983. West African Christianity: The Religious Impact (Mary Knoll: Orbis Books.

Oduyoye, M. 1969. The Planting of Christianity in Yorubaland 1842-1888, Ibadan: Daystar Press.

Ogbu U. Kalu, 1978. "Protestant Christianity in Igboland", in Ogbu U. Kalu (ed.) Christianity in West Africa: The Nigerian Story, Ibadan: Daystar Press.

Ola C.S. 1969. "Foundation of the Africa Church in Nigeria", in Modupe Oduyoye, The Planting of Christianity in Yorubaland: 1842-1888. Ibadan: Daystar Press, 251. 
Peter Falk, 1997. The Growth of the Church in Africa, Jos: African Christian Textbooks.

Toyin Falola \& Demola Babalola, 1991. "Religion and Economy in Pre-Colonial Nigeria" in J.K. Olupona and T. Fa1o1a (Eds.) Religion and Society in Nigeria (Ibadan: Spectrum Books Ltd. 